\title{
Technology and the Question of Empowerment
}

\section{Miyase Christensen \& Gavan Titley}

To cite this article: Miyase Christensen \& Gavan Titley (2014) Technology and the Question of Empowerment, Popular Communication, 12:4, 202-207, DOI: 10.1080/15405702.2014.963453

To link to this article: https://doi.org/10.1080/15405702.2014.963453

曲 Published online: 14 Nov 2014.

Submit your article to this journal ¿

LII Article views: 349

Q View related articles $\llbracket$

View Crossmark data \lceil

4 Citing articles: 1 View citing articles ๘ 


\title{
INTRODUCTION
}

\section{Technology and the Question of Empowerment}

\author{
Miyase Christensen \\ Stockholm University \\ KTH Royal Institute of Technology \\ Gavan Titley \\ National University of Ireland, Maynooth
}

Since Al Gore, in his own words, took "the initiative in creating the internet" two decades ago, much has been written about the way we produce, consume, participate, think, and live with digital media and "new" communication technologies (CNN, 1999). Gore's claim was, of course, widely parodied, but while his gallant claim has become a glib footnote in internet history, the heroic narrative of epochal transformation that he attempted to write himself into has stubbornly endured. What is it about a sizeable portion of writing on the "internet age" or "digital era" that invites — and indeed rewards_-historical myopia and novelty fetishism? Why do so many discussions of the impact and potential of the internet and new media remain shackled by the pendulum swings of optimism and pessimism, Utopian possibility, and dystopian consequence? United by a concern with technological change, media use, and questions of empowerment, the articles in this special issue on "Technology and the Question of Empowerment" seek to escape-once again - these comforting binaries. They suggest specific ways in which empowering outcomes may emerge from the adoption and adaptation of communicative resources in digitally mediated, but also socio-politically situated, environments.

That we should seek to underline the scholarly craft of contextual analysis, critical caution, and skepticism toward all-encompassing claims as a strength of this special issue says as much about the perduring force of techno-optimism as it does about the contributions themselves. As many critics have noted at this point, the prevalence of the very idea of the internet as a stable and presumably permanent entity is intrinsically problematic. Evgeny Morozov (2013), in his most recent popular critique of techno-Utopianism in public culture, To Save Everything Click Here,

Correspondence should be addressed to Miyase Christensen, Stockholm University, Department of Media Studies, Karlavägen 104, Floor 5, Box 27 861, Stockholm 115 93, Sweden. E-mail: miyase@kth.se 
traces the varieties of "epochalism" articulated over the last decades by gurus, corporations, and an often panicked and mystified media. He illustrates how both evangelicals and millenarians depend on something called "the internet" as fixed and fixer, as total and totalizing, ". . . believed to possess an inherent nature, a logic, a teleology, and that nature is rapidly unfolding in front of us" (Morozov, 2013, p. 23).

This tendency amounts to more than a mystifying lack of precision: preferring the blanket notion of the Net to more specific, and sober descriptions of networked technologies and platforms, and geopolitical formations. It can be understood as an ideology of internet-centrism, a set of beliefs that we live in unprecedented times-when do "we" not?-with unprecedented challenges but also unprecedented possibilities to "fix" human problems through the smart application of the digital. The ideological dimension of internet-centrism for Morozov lies in its production of the social world; what he terms "solutionism" determines the nature and parameters of social "problems" in accordance with the framework implied by the solution. The leaching of internet-centric solutionism into increasing fields of activity matters, it turns out, because of a foundational problem in social science- - "how problems are composed matters every bit as much as how problems are resolved" (Morozov, 2013, p. 5).

Morozov draws on Philippe Breton's call for a "secularization" of communication as a counter to the "religion" of internet-centrism (Morozov, 2013, p. 61). This secular agenda is well-established in media studies, and the contributors to this special issue contribute to it by integrating what Nick Couldry (2012) has termed the "missing social" into technology-led accounts of "new communications" and political and social processes. Marking a renewed focus on the interrelation of social theory and media and communication studies (see also Hesmondhalgh \& Toynbee, 2009) and an insistence on a "non mediacentric Media Studies" (Morley, 2009), Couldry argues that the "folding of internet information space into everyday action space" (2012, p. 3) requires the development of "socially oriented media theory, that is, theory focusing on the social processes that media constitute and enable" (p. 8, emphasis in original). It is this focus on constituting and enabling, examined in relation to specific contexts of action and historical structures of possibility, which marks the articles collected here.

Our interest in bringing them together stems, at least in part, from impatience with prevalent and insistent forms of historical myopia and technological fetishism. But before giving vent to this impatience there is room for some patient understanding. For while the clamorous championing of the interactive, networking, and participative dimensions of social media owes much to the incorporation of these practices into capital accumulation and value production (Fuchs \& Sandoval, 2014), there are also more critical and hopeful impulses in play. As Hinton and Hjorth (2013) argue, an important aspect underlying the emergence of social media is ". . . the tension between control and freedom and between exploitation and empowerment" (p. 7).

The problem is that this tension is frequently regarded as historically unprecedented, as opposed to historically situated. As David Morley notes in the interview "New Media, New Crises, New Theories? An Interview With David Morley" that follows this introduction (Christensen \& Morley, this issue), it is not clear what constitutes "non-social media"- are television, radio, newspapers, in any meaningful sense, non-social? This overdetermining of the social ignores, as Morley points out, that "newness" is a historical constant, yet while people ". . . recognise, sometimes, that other things have been 'new' before, but in their case, they believe this time it really is different—and it's just a continual delusion" (Christensen \& Morley, this issue, p. 216, emphasis in original). The pendular swing of optimism and pessimism is historically 
recurrent; television and radio were once considered progressive vehicles for social change (particularly as tools for education) while concomitantly being used as scapegoats for moral decline and increased violence. It is during the early adaptation periods for technologies-which Mosco (2005) labeled the "sublime"- that these technologies are imbued with transformative potential, mystical, liberating, threatening.

The rush to announce epochal significance, where historical sense is often blinded by the obvious fact of technological advance, obscures how all new communication technologies-papyrus, printed books, film, television, radio, internet-have been flattened out as technologies of liberation and enslavement. Thus Morley reemphasizes the significance of communication as a construct inclusive of physical mobilities as well as of the relationship between the actual and the virtual. Morley's discussion of the actual and the virtual approaches online and offline activities as deeply enmeshed with the material practices and settings of everyday life (Morley, 2011, p. 275), and replaces the falsely constructed juxtaposition of the real and the virtual.

As in time also in space; this insistence on history in Morley's interview is matched by an attention to the ". . . different contextual significance of technologies, rather than thinking of technologies simply having inherent properties which will then have automatic effects" (Christensen $\&$ Morley, this issue, p. 218). In focus here is the ways in which communications technologies have been accorded decisive roles in not just the mediation but also the mobilization and political fact of, for example, the pro-democracy movement in Egypt or the anti-government protests in Turkey. Ironically, the clear strand of "liberation technology" discourse that permeated coverage of those events risked a renaissance for hypodermic-needle style understandings of the relationship between technology, information, and user.

Morley's analysis draws attention to how, as "Western" media coverage of recent revolutionary contexts foregrounded the organizing and mobilizing importance of technological mediation, the differential significance of contextual and geographical settings was largely ignored. This emphasis on the enmeshing of technological use within movement forms and socio-political context is underlined in much of the careful empirical work now emerging on these events. In Tweets on the Streets: Social Media and Contemporary Activism, Paolo Gerbaudo (2012) provides an ethnographic account of social media use in the Arab Spring, the Occupy movement, and the Indignados movement of the squares. Gerbaudo is critical of any pendular logic.

What he terms the "techno-visionary" accounts of political action regard access to interactive and participative media as forms of counter power to oppressive state power, and as decisive factors in popular mobilization. This supposedly spontaneous mobilization of a people rising up 140 characters at a time became not only a major media focus but also a celebration of the emancipatory power of communications that says nothing about the factors that "shape the repertoire of communication of movements" (Gerbaudo, 2012, p. 2). Concomitantly, a reactive technopessimism pays too little attention to the ways in which social media facilitated the construction of shared meanings, identities, and narratives through shared political practices. What is missing from both accounts, Gerbaudo argues, is an adequate "geography of action" that recognizes that media are not in some other space-cyberspace-but central to the "recasting of spatial and temporal practices," the "choreography of assembly, the symbolic construction of public space, attempting to maintain emotional togetherness" (2012, pp. 4-9).

Such careful observation is clearly far removed from accounts where the orientalizing shadow of modernization theory informed the presumptive equation of technological possibility with democratic outcomes. Yet it is also worth noting that mediacentric and orientalist accounts of 
new technologies and political mobilization were progressively challenged "as events unfolded." As the protests in Tunisia, Libya, and Egypt developed and social media were heralded as the keys to emancipation, the very same social media - among other platforms - ensured that material and contextual considerations weakened the grip of media-centric frameworks. Questions of technological access and penetration, of the geography of mobilization, alliances, of gender, class and ethnicity, of literacy, education and mediating structures were slowly integrated into discussions of the so-called "Arab Spring" (Christensen \& Christensen, 2013). The fetishization of technology, in other words, cannot be long allowed to distract attention from the social structures and hierarchies within which such technologies are employed (Christensen, Jansson, \& Christensen, 2011), and the need to problematize our normative assumptions about them. This taps into, among other things, the critical importance of interdisciplinarity in framing questions of communication and culture, as David Morley further discusses in his interview contribution.

Beyond the reductive treatment of North African and other mass movements, it is arguably the case that the persistence of technology-led visions of democratic empowerment is born of frustrated political desire. This desire is shaped by a striking contrast, as Jeremy Gilbert argues, ". . . between a system of representative democracy which is failed and failing, and an emergent techno-social paradigm which is widely accepted as a defining force in world politics and culture and which would seem to provide the basis for a possible alternative" (2013, p. 7; a theme addressed by Joss Hands in this issue). The problem, frequently, is that investing in certain technologies as "tools for democracy" takes understandings of both the democratic form, and the viability of certain communications media to function as tools with any degree of predictability, as relatively fixed and given.

Thompson (1995, p. 5) rightly noted that "the development of communication media has not only rendered power visible in new ways, it has also rendered it visible on an unprecedented scale." However as Fenton and Titley (forthcoming) point out, a consequence of this is that our field pays significant attention to questions of media power in democracies yet very little to the ways in which representative democracies, for example, are increasingly regarded as displaying "post-democratic" characteristics (see Crouch, 2004). To use Gilbert's formulation, the "techno" is expected to compensate for the "social" and political, yet significant shifts in the social and political-particularly the hegemonic triumph of market rationality and the hollowing out of representative structures-are not registered in the transformative hopes invested in the "techno."

Likewise, as Robin Mansell (this issue) in her article entitled "Empowerment and/or Disempowerment: The Politics of Digital Media" discusses, in the institutional policy arena, economic competitiveness on the global scale is evaluated in technology and "information society" terms. This certainly is not to suggest that mediated representation of gender and minorities and digital access to, say, public services have no relevance and salience. However, within this discursive framework, issues as fundamental as feminism, gender equality, civic rights, and economic prosperity become absorbed into a narrow view, which continues to construe media and technology use as the life-blood of democratic society and social prosperity where the fundamental building blocks of democratic structures have long been under threat.

In a similar manner, the visibility of norms that underlie certain institutional formations in international policies that guide technology investments mirrors the technology-centric outlook, which discursively equates empowerment with "participation" and "openness." Robin Mansell further points our attention to the striking fact that while terms such as voice and visibility appear frequently in high-level policy discourse, others with less sex appeal such as "asymmetrical 
power" or "disempowerment" are virtually non-existent. Voice and visibility are the indices of power within an overall perspective that sees technology adoption, ultimately, as a straightforwardly positive, if political process. Celebrated as central norms, "openness" and "participation" become techno-idealist values rarely connected to the political and economic context in which political participation takes place.

In contrast to Mansell's detailed reading of institutional discourse and process, Joss Hands' (this issue) article, "General Intellect or Collective Idiocy? Digital Mobs and Social Media Mobilization," engages with the potential of digitally augmented collective action in relation to the question of how resistant collectivities emerge and sustain themselves as "we." Drawing on Marx's concept of the "general intellect," Hands notes the "pharmakological character" of digital media involves both the subsumption of labor to capital, but also a creative potential to organize, coordinate, and share. Thus he poses the question, "If social media feeds off our active general intellect, then it is incapable of becoming fully dead labor; even where capital attempts to valorize this it cannot fully capture it. The question then, is how does this operate, what is it capable of as a force of emancipation?" (Hands, this issue, p. 240).

Hands' guiding typologies of different collectivities and forms of shared consciousness provides, among other things, a timely intervention in the discussion of "agency" in relation to different forms of communicative practice. In terms of popular communication, technological mediation and popular culture remain significant sites of scrutiny for media and communication researchers, particularly due to the fact that such inquiry necessitates some reckoning with questions of power and ideology. In media and communication studies, analytic narratives have often incorporated assumptions about the emancipatory potential of technological mediations for citizens and audiences as well as marginalized groups and communities.

Recent literature on migrant media use underlines the significant role that mediation and connectivity play in the lives of people who migrate, and has provided important insights into how people experience, navigate, and act within and across socio-political contexts and cultural networks. While such practices are important and provide various forms of ontological security, solidarity and some subversive potential, they have often unproblematically been regarded as "empowering." In our experience of this field in recent years, there is arguably a form of "solutionism" at play, though one specifically marinated in cultural studies' typologies of the resistant consumer, and postracial assumptions about individual agency.

The equation of migrant/marginalized plus social media use almost always results in the validation of agency. Yet all too frequently this is a full-stop, as if the reassurance of the fact of everyday agency and creativity provides a licence to turn away from the often implacable structures of marginalization and racialization that render such resistant agency an ontological and political necessity. There is a world of difference between recognizing what Nicholas De Genova describes as the "incorrigibility" of the migrant worker-whose vitality "proceeds and exceeds any of the powers mobilized to contain and subordinate it" (2009, p. 461) —and notions of agency that strain to locate in everyday communicative practices the germ of broader emancipation.

In this regard, Koen Leurs' (this issue) article "Digital Throwntogetherness: Young Londoners Negotiating Urban Politics of Difference and Encounter on Facebook" eschews any easy detection of "cosmopolitanism" in his study of Facebook networking among multiethnic young people in Tottenham in London. Leurs adapts Doreen Massey's description of the unpredictable "throwntogetherness" of diversity and difference in urban life to frame his study of the "digitally negotiated" character of everyday urban multiculture. Leurs writes against another pendular 
dynamic, one that emphasises either the pluralizing possibilities of networked media participation or the restrictions placed on identity negotiation by the proliferation of "immaterial racism" and the decisive influence of "offline" power relations. Leurs pays attention to the ways in which Facebook facilitates the everyday maintenance of "scatteredness" among young people with significant transnational ties concomitant with its integration into an increasingly digitized urban space where what Stuart Hall termed a "multiculturalism without guarantees" provides a live horizon for the interrelatedness of young Londoners.

Overall, this special issue provides a vigilant set of accounts, drawing upon particular scholarly as well as interdisciplinary routes, of the role of technology and the study of popular communication vis-à-vis the question of empowerment. Technologically mediated forms of communication shape social relations, but the extent to which this results in "empowerment" must be assessed in terms of geopolitical situatedness, historical contingency, and the range of conjunctural elements emphasised by the authors in the special issue.

\section{REFERENCES}

Christensen, M., \& Christensen, C. (2013, July). The Arab spring as meta-event and communicative spaces. Television and New Media, 14(4), 351-364.

Christensen, M., Jansson, A., \& Christensen, C. (2011). Globalization, mediated practice and social space: Assessing the means and metaphysics of online territories. In M. Christensen, A. Jansson, \& C. Christensen (Eds.), Online territories: Globalization, mediated practice and social space (pp. 1-11). New York, NY: Peter Lang.

CNN. (1999, March 9). Transcript: Vice President Gore on CNN's “Late Edition." Archived from the original on July 26, 2010.

Couldry, N. (2012). Media, society, world: Social theory and digital media practice. Cambridge, England: Polity Press.

Crouch, C. (2004). Post-democracy. Cambridge, England: Polity Press.

De Genova, N. (2009). Conflicts of mobility and the mobility of conflict: Rightlessness, presence, subjectivity, freedom. Subjectivity, 29, 445-466.

Fenton, N., \& Titley, G. (forthcoming). Mourning and longing: Media studies learning to let go of liberal democracy. European Journal of Communication.

Fuchs, C., \& Sandoval, M. (2014). Introduction: Critique, social media and the information society in the age of capitalist crisis. In C. Fuchs \& M. Sandoval (Eds.), Critique, social media and the information society (pp. 1-47). New York, NY: Routledge.

Gerbaudo, P. (2012). Tweets and the streets: Social media and contemporary activism. London, England: Pluto Press.

Gilbert, J. (2013). Common ground: Democracy and collectivity in an age of individualism. London, England: Pluto Press.

Hesmondhalgh, D., \& Toynbee, J. (Eds.). (2009). The media and social theory. London, England: Routledge.

Hinton, S., \& Hjorth, L. (2013). Understanding social media. London, England: Sage.

Morley, D. (2009). For a materialist, non media-centric media studies. Television and New Media, 10(1), 114-116.

Morley, D. (2011). Electronic landscapes: Between the virtual and actual. In M. Christensen, A. Jansson, \& C. Christensen (Eds.), Online territories: Globalization, mediated practice and social space (pp. 273-290). New York, NY: Peter Lang.

Morozov, E. (2013). To save everything click here: Technology, solutionism and the urge to fix problems that don't exist. London, England: Penguin.

Mosco, V. (2005). The digital sublime: Myth, power, cyberspace. Cambridge, MA: MIT Press. 